\title{
Analysis of Financial Literacy Level Among Undergraduate Students
}

\author{
Ume-Tayyba Jadoon $^{1 *} \quad$ Syed-Feroz Shah ${ }^{1} \quad$ Saifullah Abro $^{1} \quad$ Ossam Chuhan ${ }^{2}$ \\ 1.Department of Basic Sciences and Related Studies, MUET, Pakistan \\ 2.Department of Mathematics, COMSATS Abbottabad, Pakistan
}

\begin{abstract}
Financial literacy has become all the time important for the economic development of a country as well as individuals for the use of economic securities. This study aims to concentrate undergraduate for understanding the need of financial literacy in the educational system according to the current situation of our society. We concentrated on the undergraduate level of financial literacy. Nowadays student financial problems are alarming. Throughout the study, they are failed to manage their financial issues. The outcomes and conclusions of this study were obtained through a questionnaire survey in undergraduate institutes. The study examines the link between financial literacy and those demographic issues that affect student financial literacy. For the purpose of an investigation, we distributed 250 questionnaire forms to random students and collect 230 from which 140 forms filled properly. The finding shows the introduction of financial literacy at an early level for the student is necessary. There is a need to reform the institutional structures to improve the capabilities of high school students and strategies that are needed to initiate financial literacy educational growth in developing areas. Additionally, due to high ratio of unemployment, they are unable to have financial experiences that affect their financial knowledge and behavior. Increasingly in the region, they have a very little approach to grow.
\end{abstract}

Keywords: Financial literacy; Demographics; Chi-Square distribution; undergraduate students.

JEL codes: G53, A22, C12, R51

DOI: $10.7176 /$ RJFA/11-14-03

Publication date:July $31^{\text {st }} 2020$

\section{Introduction}

Financial literacy becomes more important due to the rapid growth of financial instruments in the financial market. Globalization merges general products and services. Furthermore, in the same way, they affect the financial products and services. The basic knowledge of financial instruments essential to stand in an economy or a financial market. Due to less awareness of financial knowledge, less experience of financial products or services individual is facing a financial crisis. These situations are problematic for individuals, for a group of individuals may be for the economy. To face these challenges there is a need to reform the recognized institutional outlines to improve capabilities and strategies for promoting financial literacy in developing economies. There is space for groundwork in terms of research on the focus matters and the production of new policies so they can help the individual in further life in financial decision making ( Mabula. and ping. 2018).Understanding basic economic and financial concepts is the main skill for customers and depositors who want to make the right choices to achieve their economic resources over their life cycle and who contribute to fast-evolving financial markets (Fornero. and Prete. 2019).

Financial literacy education and financial literacy training are needed in early education. Literature shows short terms training of financial education program on financial literacy have a positive impact on student saving behavior. This training makes their behavior progressive and increases children's knowledge they will save for favorite product (Kalwij. et. al. 2019). While the responsibility of financial literacy education does not lie with one institution or one individual, multiple efforts have been put in place to provide financial literacy education to the public (Rakow. 2019). Occupation, financial experiences, and age are those variables that impact the behavioral biases of investors. The male investors are more confident in their stock market participation rather than female (Baker. et. al. 2019).

\subsection{Literature Review}

Investigation shows that financial literacy is positively linked with being self-employed (Cumurovic. and Hyll. 2016). Making a financial decision often goes beyond knowing and using financial issues and more effort should have been exerted by the researchers to explaining the relationship between financial literacy and any financial behavior (Aren. and Aydemir 2014). It was found that financial knowledge is determined by income, age, a stream of education, types of college, and attitude of students while it is unaffected by gender, university affiliation, financial behavior, and influence(Thapa. And Nepal 2015). Focusing on the observed evidence regarding the Big Three questions, we document that the level of financial literacy is generally rather low and we also find substantial differences between national economies and demographic associates. Individual who has general financial education is more like scoring good in financial literacy related questions as compared to less financial educated 
(Wagner 2019). The finding shows regional differences affect financial literacy if the difference in structural characteristics are taken into account and their financial inclusion may be different (Ozdemir. et. al. 2019). There is considerable geographic variation in financial literacy that only a few studies are beginning to document. As discussed in the literature, some of these differences are due to demographic and economic characteristics across states, but these variables cannot explain all of these differences (Bumcrot. et. al. 2011). In developing countries financial literacy directly linked with the level of financial market development and social demographic factor. These types of economies need various financial literacy development programs that should be implemented to suit their economic position for their growth. For these purposes there is a need for the enhancement of policies and restructure the institutional frameworks for adults (Mabula And Ping 2018). Financial literacy plays a significant role in the economic growth of a country and financial education programs impact positively at the workplace that increases the efficiency in financial policies and profitability of firms (Custodio. et. al. 2019). In particular, financial literacy turns out to be considerably lower in transition economies and lower-income economies as compared to industrial economies (Klapper.et al. 2015).

Higher levels of financial literacy were found among the subgroup of students who financed their university education through bank loans compared to the groups that financed their studies through financial support by family The study also found that students who participated in family financial decisions and those who have taken money management course are more likely to be financially literate (Oseifuah and Gyekye 2014). Literature shows women are less financially literate and less like to plan for future and have less financial experiences although live long life as compared to male, who have more financial experiences (Lusardi and Mitchell 2018). Increasingly females, less educated population and poor young are suffer due to less knowledge of finance. Little financial knowledge intensifies the consumer and complex financial instrument increase the financial market risk (Klapper and Lusardi 2019). But households with low housing value more like to participate in the financial market as compared to a household with high housing value (Zou and Deng 2019).

In different findings, we observed that more investment information was increased from a college personal finance lecture as compared to high school (Peng et al. 2007). Financial education for youth designed on primarily level and practice immediate financial problems for improvement of financial decisions related to a particular financial matter in daily life (Walstad. et. al. 2010). Financial literacy can be involved in compulsory education curricula, and numerous countries are changing national plans that consist of young financial literacy programs that are work to increase financial inclusion and increase consumer protection (OECD, 2015). That situation shows financial knowledge more depend on financial practices. We have to expose the need for the interest of youth in financial matters. The interest of the youth raised by motivation, when they are young students. We should work to present positive effects of financial knowledge so as they mature this aiding them to manage their personal financial matters and they can enter with a higher level of financial literacy to adulthood (Bongini. et. al. 2015). It is students necessity improve their personal finance knowledge because at that time most students enter practical life. If the individuals are not to be able to their finances, it may create a large problematic condition not only for them but for the society where they survive (Sarigul 2014).

\section{Research Methods}

2.1 Objectives

The objective of the present study are

- To study impact of demographic factors on financial literacy.

- To develop a correlation between the effective factors and financial literacy.

\subsection{Procedure}

To achieve the required result and assumption of the work, we prepare a questionnaire and survey for undergraduate institutes of region Mirpurkhas. A total of 250 participants take part when the questionnaire was checked thoroughly only a few respondents response properly. These questionnaires were contained demographic factors and big three important financial Knowledge question which are used on an international level such as information of compound interest, inflation and stock market participation. Data collection and analysis took place in the academic year 2019 according to the lecture schedule at participating institutes. Convenience sampling method is practiced in this investigation to choose participants as well as the study target educational institutes on the basis of easy access and availability of data. The research survey that has been applied used quantitative technique. The questionnaires were given to the respondents face to face, the response rate was $56 \%$.

Data analysis was conducted using the Statistical Package for Social Sciences Software (SPSS). To answer the research questions, a three-phase statistical analysis was completed: First, descriptive analysis, frequency distributions, and percentages were used to describe the sample according to their demographic factors. Second, the chi-square distribution is used to determine the association between predictors and outcome variable and third, bivariate analysis such as spearman's correlation was computed to examine the relationship between predictor and outcome variable. 


\section{Results}

Table no 1 shows only 52 female with (37.2\%) and 88 male with (62.8\%) response sensibly from which 15 with $(10.7 \%)$ were married and $125(89.3 \%)$ are unmarried/single persons. Overall, almost half of the respondents of the samples were at the age between 22 and 25 years (51.4\%), while the age band 17-21 were with (40\%) and only $(8.6 \%)$ of respondents were of age more than 25 years. The population comprised a student of health Sciences 22 with (15.7\%), bachelor in Computer Sciences 78 with (55.7\%) and bachelor in Business Administration 40 $(28.6 \%)$. The students participate according to their level of studies $1^{\text {st }}$ year 31 students with $(22.1 \%), 2^{\text {nd }}$ year 32 students with $(22.8 \%), 3^{\text {rd }}$ year 36 students with $(25.7 \%)$ and $4^{\text {th }}$ year 41 students with $(29.3 \%)$. Most of the students were unemployed they don't have personal monthly income 96 students with (71.4\%) and fewer 15 students were have personal monthly income less than $5 \mathrm{k}$ with $(10.7 \%), 5 \mathrm{k}-10 \mathrm{k}$ personal monthly income were have 19 students with (12\%) and more than 10k personal monthly income have 10 students with (6.4\%). The 97 students didn't like to record their expenses with (70\%) and fewer 43 students like to record their expenses with (30\%). As most of the 84 students did not have a personal income they did not have savings with $(60 \%)$ and 56 students have saving with (40\%). Out of those students which are unemployed 50 students were looking for work with (35.7\%) and 27 students were part time employee with (19.3\%), 17 students were self-employee with (12.1\%) and 46 students were not looking for work with $(32.8 \%)$. All working student work in non-financial organization. 24 students who works less than 5hour were (17.1\%) and 20 students work more than 5hour (14.3\%). The house hold income less than $20 \mathrm{~K}$ have 16 students with (11.4\%), household income between $20 \mathrm{k}-40 \mathrm{~K}$ have 61 students with $(42.8 \%)$ and household income more than $40 \mathrm{~K}$ have 63 students with $(45 \%)$.

Table no 1: Demographic Characteristics of the Sample Population $(\mathrm{N}=140)$

\begin{tabular}{|c|c|c|c|}
\hline Characteristics & $\begin{array}{l}\text { Number of } \\
\text { respondents }\end{array}$ & $\begin{array}{l}\text { Percentage of } \\
\text { respondents }\end{array}$ & $\begin{array}{l}\text { Mean percentage of correct } \\
\text { answers }\end{array}$ \\
\hline \multicolumn{4}{|l|}{ Gender } \\
\hline a) Female & 52 & 37.2 & 21.1 \\
\hline b) Male & 88 & 62.8 & 53.4 \\
\hline \multicolumn{4}{|l|}{ Marital Status } \\
\hline a) Single & 125 & 89.3 & 40 \\
\hline b) Married & 15 & 10.7 & 53.3 \\
\hline \multicolumn{4}{|l|}{ Age Bands } \\
\hline a) $17-21$ & 56 & 40 & 23.2 \\
\hline b) $22-25$ & 72 & 51.4 & 52.7 \\
\hline c) more than 25 & 12 & 8.6 & 58.3 \\
\hline \multicolumn{4}{|l|}{ Field of education } \\
\hline a) Health sciences & 22 & 15.7 & 22.7 \\
\hline b) Engineering & 78 & 55.7 & 44.8 \\
\hline c) Business & 40 & 28.6 & 45 \\
\hline \multicolumn{4}{|l|}{ Level studies } \\
\hline a) 1 Year & 31 & 22.1 & 25.8 \\
\hline b) 2 Year & 32 & 22.8 & 21.8 \\
\hline c) 3 Year & 36 & 25.7 & 47.2 \\
\hline d) 4 Year & 41 & 29.3 & 63.4 \\
\hline \multicolumn{4}{|l|}{ Personal monthly income } \\
\hline a) Not applicable & 96 & 68.6 & 34.3 \\
\hline b) less $5 \mathrm{k}$ & 15 & 10.7 & 53.3 \\
\hline c) $5 \mathrm{k}-10 \mathrm{k}$ & 19 & 13.6 & 63.1 \\
\hline d) More than $10 \mathrm{k}$ & 10 & 7.1 & 50 \\
\hline \multicolumn{4}{|l|}{ Record of expense } \\
\hline a) $\mathrm{No}$ & 97 & 69.3 & 39.1 \\
\hline b) Yes & 43 & 30.7 & 46.5 \\
\hline \multicolumn{4}{|l|}{ Saving } \\
\hline a) $\mathrm{No}$ & 84 & 60 & 38 \\
\hline b) Yes & 56 & 40 & 46.4 \\
\hline \multicolumn{4}{|l|}{ Current work situation } \\
\hline a) Not looking for work & 46 & 32.8 & 17.4 \\
\hline b) Looking for work & 50 & 35.7 & 50 \\
\hline c) Part time & 27 & 19.3 & 60 \\
\hline d) Self employed & 17 & 12.1 & 58.8 \\
\hline
\end{tabular}




\begin{tabular}{|c|c|c|c|}
\hline Characteristics & $\begin{array}{c}\text { Number of } \\
\text { respondents }\end{array}$ & $\begin{array}{c}\text { Percentage of } \\
\text { respondents }\end{array}$ & $\begin{array}{c}\text { Mean percentage of correct } \\
\text { answers }\end{array}$ \\
\hline Working organization & & & 34.4 \\
\hline a) Refused & 96 & 68.6 & 56.8 \\
\hline b) Non-financial org & 44 & 31.4 & 34.4 \\
\hline Working hour & & & 50 \\
\hline a) Refused & 96 & 68.6 & 65 \\
\hline b) Less than 5h & 24 & 17.1 & 37.5 \\
\hline c) More than 5h & 20 & 14.3 & 50.8 \\
\hline House hold income & 16 & & 33 \\
\hline a) Less than 20k & 61 & 11.4 & 42.8 \\
\hline b) 20K-40k & 63 & 45 & \\
\hline c) More than 40k & & & \\
\hline
\end{tabular}

\subsection{Chi-square distribution}

Chi- square distribution is used to testing the association between categorical variables. The null hypothesis for this test was $\mathrm{H}_{0}=$ there is no association between the financial literacy and defined demographic variable (e.g Gender, marital status, age, etc) and the alternative hypothesis was $\mathrm{H}_{\mathrm{A}}=$ there is an association between financial literacy and defined demographic variables. The significance level $\mathrm{P}=0.5$.

Table no 2 examines the association between financial knowledge and sociodemographic variables (gender, marital status, age, etc), using chi-square test. As shown in Table no 2, there was a moderate significant relationship among financial knowledge and gender, $\chi 2(1,140)=14.014, \mathrm{p}<.05$, Cramer's $\mathrm{V}=0.316$. Gender categorized as male reported more right answer percentage (53.4\%) as compared to females (21.2). Age bands shows moderate association $\chi 2(2,140)=12.892, p<.05$, Cramer's $\mathrm{V}=303$. Table 2 shows as age bands change $1^{\text {st }}, 2^{\text {nd }}$ and $3^{\text {rd }}$ their right answer percentage increases from $(23.2 \%),(52.8 \%)$ and $(58.3 \%)$ respectively. Other variables such as marital status, Field of education, Personal monthly income, the record of expenses, savings and House hold income are not significantly associated with financial knowledge. Level of studies were positively associated with financial literacy $\chi 2(3,140)=16.826, p<.05$, Cramer's $V=.347$ as level of education categories move $1^{\text {st }}$ to $2^{\text {nd }}$, $3^{\text {rd }}$ and $4^{\text {th }}$ their right answer percentage increases as $(25.8 \%),(21.9 \%),(47.2 \%)$ and $(63.4 \%)$. Current work situation has values $\chi 2(3,140)=16.808, \mathrm{p}<.05$, Cramer's $\mathrm{V}=.346$. Working situation has positive impact as their working condition change their response ratio also change and it goes high $1^{\text {st }}$ condition(not looking for work) $(17.4 \%), 2^{\text {nd }}$ condition(looking for work) $(50 \%), 3^{\text {rd }}$ condition(part-time employed) $(55.6 \%)$ and $4^{\text {th }}$ condition(selfemployed) (58.8\%).

Table no 2: Chi-Square Distribution of Demographic factors by Level of Financial Literacy

\begin{tabular}{|c|c|c|c|c|c|c|}
\hline Characteristics & $\begin{array}{c}\text { False } \\
(\%) \\
\end{array}$ & $\begin{array}{l}\text { True } \\
(\%)\end{array}$ & Total & $X^{2}$ & $\begin{array}{c}\text { Phi \& } \\
\text { Cramer V }\end{array}$ & $\begin{array}{c}\text { Contingency } \\
\text { Coefficient }\end{array}$ \\
\hline \multicolumn{7}{|l|}{ Gender } \\
\hline a) Female & $41(78.8)$ & $11(21.2)$ & 52 & 14.014 & .316 & .302 \\
\hline b) Male & $41(46.6)$ & $47(53.4)$ & 88 & & & \\
\hline \multicolumn{7}{|l|}{ Marital Status } \\
\hline a) Single & $75(60)$ & $50(40)$ & 125 & .981 & .084 & .083 \\
\hline b) Married & $7(46.7)$ & $8(53.3)$ & 15 & & & \\
\hline \multicolumn{7}{|l|}{ Age Bands } \\
\hline a) $17-21$ & $43(76.8)$ & $13(23.2)$ & 56 & 12.892 & .303 & .290 \\
\hline b) $22-25$ & $34(47.2)$ & $38(52.8)$ & 72 & & & \\
\hline c) More than 25 & $5(41.7)$ & $7(58.3)$ & 12 & & & \\
\hline \multicolumn{7}{|l|}{ Field of education } \\
\hline a) Health sciences & $17(77.3)$ & $5(22.7)$ & 22 & 3.762 & .164 & .162 \\
\hline b) Engineering & $43(55.1)$ & $35(44.9)$ & 78 & & & \\
\hline c) Business & $22(55)$ & $18(45)$ & 40 & & & \\
\hline \multicolumn{7}{|l|}{ Level studies } \\
\hline a) $1^{\text {st }}$ Year & $23(74.2)$ & $8(25.8)$ & 31 & 16.826 & .347 & .328 \\
\hline b) $2^{\text {nd }}$ Year & $25(78.1)$ & $7(21.9)$ & 32 & & & \\
\hline c) $3^{\text {rd }}$ Year & $19(52.8)$ & $17(47.2)$ & 36 & & & \\
\hline d) $4^{\text {th }}$ Year & $15(36.6)$ & $26(63.4)$ & 41 & & & \\
\hline
\end{tabular}




\begin{tabular}{|c|c|c|c|c|c|c|}
\hline Characteristics & $\begin{array}{c}\text { False } \\
(\%)\end{array}$ & $\begin{array}{l}\text { True } \\
(\%)\end{array}$ & Total & $x^{3}$ & $\begin{array}{c}\text { Phi \& } \\
\text { Cramer V }\end{array}$ & $\begin{array}{c}\text { Contingency } \\
\text { Coefficient }\end{array}$ \\
\hline \multicolumn{7}{|l|}{ Personal monthly income } \\
\hline a) Not applicable & $63(65.6)$ & $33(34.3)$ & 96 & 6.844 & .221 & .216 \\
\hline b) less $5 \mathrm{k}$ & $7(46.7)$ & $8(53.3)$ & 15 & & & \\
\hline c) $5 \mathrm{k}-10 \mathrm{k}$ & $7(36.8)$ & $12(63.2)$ & 19 & & & \\
\hline d) More than $10 \mathrm{k}$ & $5(50)$ & $5(50)$ & 10 & & & \\
\hline \multicolumn{7}{|l|}{ Record of expense } \\
\hline a) $\mathrm{No}$ & $59(60.8)$ & $38(39.2)$ & 97 & .661 & .069 & .069 \\
\hline b) Yes & $23(53.5)$ & $20(46.5)$ & & & & \\
\hline \multicolumn{7}{|l|}{ Saving } \\
\hline a) $\mathrm{No}$ & $52(61.9)$ & $32(38.1)$ & 84 & .962 & 0.83 & .083 \\
\hline b) Yes & $30(53.6)$ & $26(46.4)$ & 56 & & & \\
\hline \multicolumn{7}{|l|}{ Current work situation } \\
\hline $\begin{array}{l}\text { a) Not looking for } \\
\text { work }\end{array}$ & $38(82.6)$ & $8(17.4)$ & 46 & 16.808 & .346 & .327 \\
\hline $\begin{array}{l}\text { b) Looking for } \\
\text { work }\end{array}$ & $25(50)$ & $25(50)$ & 50 & & & \\
\hline c) Part time & $12(44.4)$ & $15(55.6)$ & 27 & & & \\
\hline d) Self employed & $7(41.2)$ & $10(58.8)$ & 17 & & & \\
\hline \multicolumn{7}{|l|}{ Working organization } \\
\hline a) Refused & $63(65.6)$ & $33(34.4)$ & 96 & .263 & .212 & .207 \\
\hline $\begin{array}{l}\text { b) Non-financial } \\
\text { org }\end{array}$ & $19(43.2)$ & $25(56.8)$ & 44 & & & \\
\hline \multicolumn{7}{|l|}{ Working hour } \\
\hline a) Refused & $63(65.6)$ & $33(34.4)$ & 96 & 7.274 & .228 & .222 \\
\hline b) Less than $5 \mathrm{~h}$ & $12(50)$ & $12(50)$ & 24 & & & \\
\hline c) More than $5 \mathrm{~h}$ & $7(35)$ & $13(65)$ & 20 & & & \\
\hline \multicolumn{7}{|l|}{ House hold income } \\
\hline a) Less than $20 \mathrm{k}$ & $10(62.5)$ & $6(37.5)$ & 16 & 4.020 & .169 & .167 \\
\hline b) $20 \mathrm{~K}-40 \mathrm{k}$ & $3049.2)$ & $31(50.8)$ & 61 & & & \\
\hline c) More than $40 \mathrm{k}$ & $42(66.7)$ & $21(33.3)$ & 63 & & & \\
\hline
\end{tabular}

\subsection{Bivariate correlation}

Table 3 examine if there were any correlation between financial literacy and demographics. Shows financial literacy significantly correlated with gender $r(140)=.316, P<0.5$, Age bands $r(140)=.296, P<.05$, Level of studies $r(140)=.325, P<.05$, Personal monthly income $r(140)=.207, P<.05$, Current work situation $r(140)=.332, P<.05$, Working organization $r(140)=.212, P<.05$, Working hour $r(140)=.224, P<$ .05 . 
Table no 3: Spearman's rho correlations among financial knowledge and effective factors

\begin{tabular}{|c|c|c|c|c|c|c|c|c|}
\hline $\begin{array}{l}\text { Spearman's } \\
\text { rho }\end{array}$ & $\begin{array}{l}\text { financial } \\
\text { literacy }\end{array}$ & Gender & $\begin{array}{l}\text { Age } \\
\text { bands }\end{array}$ & $\begin{array}{l}\text { Level } \\
\text { of } \\
\text { studies }\end{array}$ & $\begin{array}{l}\text { Personal } \\
\text { monthly } \\
\text { income }\end{array}$ & $\begin{array}{l}\text { Current } \\
\text { work } \\
\text { situation }\end{array}$ & $\begin{array}{l}\text { Working } \\
\text { org: }\end{array}$ & $\begin{array}{l}\text { Working } \\
\text { Hour }\end{array}$ \\
\hline \multirow{2}{*}{$\begin{array}{l}\text { financial } \\
\text { literacy }\end{array}$} & 1.000 & $.316^{* *}$ & $.296^{* *}$ & $.325^{* *}$ & $.207^{*}$ & $.322^{* *}$ & $.212^{*}$ & $.224^{* *}$ \\
\hline & & .000 & .000 & .000 & .014 & .000 & .012 & .008 \\
\hline \multirow[t]{2}{*}{ Gender } & & 1.000 & .056 & .029 & $.254^{* *}$ & $.315^{* *}$ & $.266^{* *}$ & $.314^{* *}$ \\
\hline & & & .508 & .736 & .002 & .000 & .002 & .000 \\
\hline \multirow[t]{2}{*}{ Age bands } & & & 1.000 & $.722^{* *}$ & .036 & $.184^{*}$ & .038 & .048 \\
\hline & & & & .000 & .672 & .029 & .653 & .575 \\
\hline \multirow[t]{2}{*}{$\begin{array}{l}\text { Level of } \\
\text { studies }\end{array}$} & & & & 1.000 & .032 & .147 & .006 & .014 \\
\hline & & & & & .709 & .082 & .939 & .873 \\
\hline \multirow{2}{*}{$\begin{array}{l}\text { Personal } \\
\text { monthly } \\
\text { income }\end{array}$} & & & & & 1.000 & $.830^{* *}$ & $.980^{* *}$ & $.938^{* *}$ \\
\hline & & & & & & .000 & .000 & .000 \\
\hline \multirow{2}{*}{$\begin{array}{l}\text { Current } \\
\text { work } \\
\text { situation }\end{array}$} & & & & & & 1.000 & $.843^{* *}$ & $.820^{* *}$ \\
\hline & & & & & & & .000 & .000 \\
\hline \multirow{3}{*}{$\begin{array}{l}\text { Working } \\
\text { organ. }\end{array}$} & & & & & & & 1.000 & $.944^{* *}$ \\
\hline & & & & & & & & \\
\hline & & & & & & & & .000 \\
\hline $\begin{array}{l}\text { Working } \\
\text { Hour }\end{array}$ & & & & & & & & 1.000 \\
\hline
\end{tabular}

\section{Conclusion}

This work aims to cast light on the problem of financial literacy and to present existing capabilities of students and the current situation in the region for financial literacy at undergraduate level. Findings show it is necessary being fluent with numbers and financial concepts. Individual need abilities to understand numbers with the financial concept so they can participate confidently in numerous financial decisions related to their daily activities. If we need to increase understandings about financial literacy among students, we need to upgrade toolbox of financial literacy with finer instruments like the financial educational programs at the high school level are one of the most improved and available education-based solutions. The increase in financial literacy is a way to increase empowerment and improve the quality of life. We spent energy, thoughts and time to pursuing money and financial literacy will help in limiting the unnecessary waste of money. Thus, when student gain more knowledge of financial literacy they will show more positive attitudes toward money and they will make better choices, which will save assets and improve their financial conditions. This study reveals low level of financial literacy among the students in the region.

\section{References}

Aren, S., \& Aydemir, S. D. (2014). A literature review on financial literacy. https://doi.org/10.14784/JFRS.2014117326, ISSN 1309-1123, 6(11), 33-49.

Baker, H. K., Kumar, S., Goyal, N. \& Gaur, V. (2019). How financial literacy and demographic variables relate to behavioral biases. Managerial Finance, 45(1), 124-146.

Bongini, P., Trivellato,P. \& Zenga, M. (2015). Business students and financial literacy: when will the gender gap fadeaway. Journal of financial management markets and institutions, 3(1), 13-30.

Bumcrot, C. B., lin, J. \& Lusardi, A. (2011). The geography of financial literacy. Financial literacy center working paper. 2-16.

Ćumurovic, A. \& Hyll, W. (2016). Financial literacy and self-employment. IWH discussion papers no. 11/2016, $1-21$.

Custodio, C., Mendes, D. \& Metzger, D. (2019). The impact of financial literacy on medium and large enterprisesEvidence from randomized controlled trial in Mozambique. SSRN, 63.

Fornero, E. \& Prete, A. L. (2019). Voting in the aftermath of a pension reform: the role of financial literacy. Journal 
of pension economic and finance, 18(1), 1-30.

Kalwij, A., Alessie, R., Dinkova, M., Schonewille, G., Schor, A. V. D. \& Werf, M. V. D. (2019). The effects of financial education on financial literacy and savings behavior: evidence from a controlled field experiment in dutch primary schools. The Journal of Consumer Affairs, 53(3), 699-730.

Klapper, L. \& Lusardi, A. (2019). Financial literacy and financial resilience: Evidence from around the world. Financial management A.

Klapper, L., Lusardi, A. \& Oudheusden, P. V. (2015). Financial literacy around the world: http://www.FinLit.MHFI.com.

Lusardi, A. \& Mitchell, O. S. (2018). Planning and financial literacy: how do women fare? National bureau of economic research working paper 13750, 1-10.

Mabula, J. b. \& Ping, H. D. (2018). Financial literacy position in developing economies: a review of studies and open issues. 2nd International conference on social science, public health and education (SSPHE 2018), 2019, Published by Atlantis Press, 196, 277-281.

OECD (2015). National strategies for financial education: OECD/INFE Policy Handbook.

Oseifuah, E. K. \& Gyekye A.B. (2014). Analysis of the level of financial literacy among South African undergraduate students. Journal of economics and behavioral studies. 6(3), 242-250.

Ozdemir, K. K., Kokkizil, M. \& Uysa, G. (2019). Financial literacy in developing countries. Social Indicator Research, 143(1), 325-353.

Peng, T.M., Bartholomae, B., Fox, J. J. \& Cravener G. (2007).The impact of personal finance education delivered in high school and college courses. Journal of family and economic issues 28, 265-284.

Sarigul, H. (2014). A survey of financial literacy among university students. Journal of accounting and finance, 207-224..

Thapa, B. S. \& Nepal, S. R. (2015). Financial Literacy in Nepal: A Survey Analysis from College Students, NRB Economic review, 49-74.

Wagner, J. (2019). Financial education and financial literacy by income and education group. Economic faculty publications, 65 .

Walstad W. B., Rebeck, K. \& Macdonald R. A. (2010). The effects of financial education on the financial knowledge of high school students. The Journal of Consumer Affairs, 44(2), 336-357.

Zou, J. \& Deng, X. (2019). Financial literacy, housing value and household financial market participation: Evidence from urban China. China Economic Review, 55, 52-66. 